\title{
A Second-Class Workforce: How Neoliberal Policies and Reforms Undermined the Educational Profession
}

\author{
Sunni Ali ${ }^{1, *}$ \\ ${ }^{1}$ College of Education, Northeastern Illinois University, Chicago, USA \\ *Correspondence: College of Education, Northeastern Illinois University, Chicago, USA. E-mail: Asunni@neiu.edu
}

Received: May 17, 2019

Accepted: July 15, 2019 Online Published: August 21, 2019

doi:10.5430/jct.v8n3p102

URL: https://doi.org/10.5430/jct.v8n3p102

\begin{abstract}
Years of professional neglect, scrutiny, and inequitable pay have forced educators across the country to fight for improved policies and reforms. A public, in some circles, that views educators undeserving of their salaries due to the unpreparedness of the American youth to succeed in the economy and the continued societal problems emanating from the profession.

Neoliberalism, as a school policy plan, was designed to retool and establish improved schooling opportunities, especially for children of color located in poor residential environments. Instead, what it created was a more divided, tiered school arrangement that expelled black-and-brown teachers from education while closing down the schools they worked in primarily situated in urban America (Lipman, 1998; Watkins, 2011; Apple, 2018).

The methodology for this research diagnosed and assessed key aspects of contemporary literature along with applying an auto-ethnographic lens to evaluate school reform challenges. The critical race theoretical approach was adopted to indicate how neoliberalism affects new teachers entering the profession along with teachers and children of color existing within school structures.

Despite the paper identifying the various milestones achieved in the newly constructed schools, it is also clear that charter-and-contract school designs pay teachers less for their work, reduces the employment attrition rate, and consummates an over testing industry that regulates and controls how teachers instruct and are evaluated. More troubling, fewer people were interested in pursuing this profession as a career (Walker, 2019; Ravitch, 2016).

To fix this challenge, educators are in the streets, the school board rooms, and on Capitol Hill to demand their profession receive the types of reforms necessary to sustain its existence. Such activism ensures education will continue to make great strides improving the lives of children, every day, while also working to sustain communities in need of hope and progress.
\end{abstract}

Keywords: culturally responsive, neo-liberalism, social justice, educational reform

\section{An Educator's Paradox}

As educators swarm the streets of major cities demanding reform and appeals in their profession, a new beginning for teachers has begun. Today's teachers are seeking to ameliorate neoliberal educational policies that worked to destroy teacher unions, underpay state-licensed educators, and vanish challenged schoolhouses seen as a burdened to taxpayers. Such educational discontentment and change-agency experienced by teaching practitioners are similar to how engineers in the early 20th-Century reversed Chicago's river, which helped to expand the lakefront area (Hill, 2019). Only this time, instead of reversing a river, educators are shifting how society chooses to value, control, and commodify their profession.

Teachers are the only skilled-credentialed population that does not control their industry (Ravitch, 2016). Medical doctors, lawyers, college professors, police officers, and so many other licensed professionals manage their industry as they sit on boards or evaluation posts deciding the future of their cottage. With the profession being predominantly women, about $76 \%$ which accounts for three-in-four educators being females, it is alleged education remains undervalued and unappreciated because of the gender-income gap that continues to consume the economy (Wong, 2019). Teaching, too often, is equated with babysitting learners versus preparing young people to participate in the 
economy. Moreover, codified within this message is that it is not worth investing in minority students who are too often seen as academically inept and incapable of achieving educational standards. As the former mayor of Chicago once declared, according to the Union President, Karen Lewis, "That 25 percent of the students in this city are never going to be anything, never going to amount to anything and he was never going to throw money at them" (Ahern, pg. 1). Of course, the mayor denies such racist verbiage came from his mouth despite the CTU president swearing up-and-down he stated this. However, how many times are such feelings or beliefs discussed privately behind closed doors within households, commercial offices, or governmental dwellings?

Years of racist school practices and neglect of urban black and brown populations certainly have not helped educators' cause to receive fair pay due to historic failings from far too many schoolhouses that sanctioned a school-to-prison-pipeline- a colloquial phrase used to describe how the dropout rate contributes to juvenile delinquency rate and incarceration. Also, any additional funds such as an increase of tax dollars to adequately equip educators with the necessary resources to intellectually arm teachers-and-students became viewed as a waste of money (Watkins, 2011; Apple, 2018).

Despite the increase preparatory credentialing and testing educators have to acquire to stand in front of children along with completing additional professional development hours, too many teachers who work in urban school arrangements are perceived as undeserving of the salary they receive. Moreover, many educators continue to make strides advancing culturally responsive practices which have helped to edify the nation's plurality notions of diversity while equipping generations of Americans with skills to function and compete in the economy. Yet, a segment of the teaching workforce remains viewed as inferior and failed professionals (Ravitch, 2016; Chicago Public Schools, 2012). Hence, schoolhouses closed as teachers were laid off or fired. The teachers who sought work elsewhere often had to wear the Scarlett Letter A, which identified them as failed educators deserving of less pay seeking employment at a charter school.

\section{Renaissance 2010}

More than 15-years ago since Chicago's adopted Renaissance 2010 model, the city's education reform construct, a new set of urban schools emerged that displaced many black educators while at the same time lowering teachersalaries (Ottoberg, 2019). Such a reform affected not only educators and students, but also the families and communities that either lost their school or received a new one. The city's outgoing mayor, Rahm Emmanuel, is not only infamous for closing more than 54-plus schools during this era but also advanced a three-tiered model and arrangement of schools earmarked as privileged, stable and quality, and subpar (Author, 2016; Lipman, 2011; Apple, 2018).

Privileged schools were designed to keep upper middle-income whites in the city to avoid them fleeing to the Northern and Western suburban school districts (Lutton, 2012). Schools such as Walter Payton, North Side Prep, and Jones College Prep are elite models that serve specific student populations of the city considered exceptional and scholastic. Entry into these schools is very competitive, and the qualifications to achieve enrollment is based on high-test scores and grades of straight As. Indeed, some argue it is easier for Chicago students to achieve entry into an elite college, such as Harvard, Yale, Princeton versus a first-tier Chicago high school (Barnum, 2016).

The stable and quality schools fall more under the heading of middle-tier constructed for learners who were unable to attend the first-tier schools but also are considered outstanding or good students. In some ways, these schools are ideal because parents were provided more options for their students to attend newly developed charter or contract schools as opposed to attending a challenged neighborhood school. Some scholars argued that such schools have helped to create new instructional pathways and educational opportunities for disadvantaged groups residing in challenged geo-spaces due to the failure showcased in community schools (Lake and Rainey, 2005; Rand Corporation, 2019). Too often, school failure perpetuated dropout factories where low-expectations permeated bigotry. In other words, Charter and contract schools enhanced a viable school alternative and choice for families worried about sending their children to troubled public schoolhouses.

The disadvantaged spaces, referred to as subpar, were neglected school arrangements that never received adequate and fair funding due to a state's funding formula and per-pupil expenditure calculations (Apple, 2018; Kozol, 2006). Historically, the funding mechanism for schools applies a community's property tax dollars. Areas that were poor or that had less property tax revenue received less money for their schools; whereas, a neighborhood with a higher property tax value acquired more resources toward their schools. Although this funding system has been changed in 
states such as Illinois, replaced with a more equitable tax funding mechanism to financially assist struggling school districts, especially for those schools located in rural areas downstate, the damage already happened.

As Kozol $(2006 ; 2012)$ notably examined, a state applying property tax as a monetized system to fund schools intentionally chose family privilege over equality by undermining poorer or fiscally challenged community schoolhouses with a chance to provide quality education to students. Many of the schools in this tier barely held any updated books, had a library, provided a quality gym facility, and scrapped by providing toilet paper and hand soap for bathrooms (Kozol, 2006; Lipman, 1998). Teachers working in these schools often left after a few years before "burning out" or fleeing the profession. Furthermore, schools in this tier had a challenged population of learners whose families struggled with poverty, often resided in high-crime areas, and encountered other various forms of trauma. Hence, the students in these schools required a great deal of support that neither the schools had the money for or the resources to service the learners, e.g., mental health specialist, therapeutic counselor, school psychologist, academic support specialist (Wexler, 2018; Hursh, 2006)

Looking at today's schools in Chicago, if a student does not attend a first or second tier school, they will struggle to achieve a quality education. Since about $20 \%$ of the city's student population attend an elite school, many parents are left hardly any options except to send their child to a charter or contract school if their community schoolhouse is considered inferior or does not resemble schools like Von Stuben High School or Kenwood Academy (Lutton, 2012). Also, according to the Chicago Reporter's article entitled, "And You Thought Getting Into the Ivies Was Hard-Try These Chicago High Schools,

In 2011, half of Chicago's elementary schools sent no one, not even their top students, to the four best high schools, which coincidentally got a third of their students from wealthy private elementary schools, according to a WBEZ report. Today, whites make up 9.4 percent of CPS' student body but are between 38 and 48 percent of students at the top public high schools (pg. 2).

The elite models were designed to mostly service white-middle income family populations. Families that cannot send their children to a top tier school or a quality charter end up leaving the city for greener educational pastures (Godsey, 2015). Hence, this explains why the enrollment in so many of the community schools is low and leads to more school closings. Some community schoolhouses that once held a 2000 population of learners are down to 150 to 200 students. Many of the buildings or campuses are underused, and taxpayers are responsible for footing the bill to pay for gas, water, electricity, internet, and security monitoring systems for empty warehouses. There remains one main reason why these schools have not been shut down: the political fallout and social challenges that occurred from the last slate of school removals viewed as harshly imposed and destabilizing for many parents, students, and communities. The victims of these school closings struggled to send their children to nearby schools that were often dangerous to attend due to inter-gang and opposing gang rivalry boundary lines. Also, many of these schools were academically worse than the students' previous educational residence.

The now vacated, empty buildings are a testimony to Chicago's Renaissance 2010 that believed these failing schools were no longer worth the city and taxpaying public efforts. Hence, these schools were left to die and, in their place, came new schools marketed to venture capitalist and philanthropist to create new schools for the city's residents desperate for quality schools for their children (Lipman, 2011; Watkins, 2011). The privatized-public institutional mechanism would emerge which promised better results at a cheaper cost to the taxpaying public.

\section{Neoliberal Trends Led to Privatized-Public Schools}

Although Neoliberalism presents a liberal method to administer social and economic policies to state and city governments, a Keynesian posit, the word neo does not mean new and functions as a different definition. Neoliberalism, as viewed by some scholars, is a modern economic-policy system that allows for the privatization of public domains such as, schools, parking, transportation, and certain municipal domains (Ravitch, 2000; Chomsky, 2015). The policy of Neoliberalism assumes that since Laisezz-Faire capitalism or the free-market improves the quality of life for people living in society, the market requires further capital expansion into the public sphere to maintain economic and social stability. Neoliberal policy supporters argue the welfare state, poor policy planning, and municipalities' mismanagement of fiscal budgets all but drained local governments from having the ability to provide quality public services, specifically to working class and marginalized groups (Davies, 2016; Wait, 2017).

The neoliberal theory assumed that broke municipalities could no longer sustain public social systems without relying on private entities and companies to support a new generation of social capital programs to empower targeted groups to become stabilized, independent, and productive members in the economy. In other words, states were financially 
weary or broke and required additional funding, revenue, and resources to equip marginalized, underperforming, and challenged schoolhouses. Some scholars assert that the United States' Neo-liberal construct emerged during Regan's presidency in the early 80 s when many cities across the nation struggled with poverty, crime, drugs, and failing schools, and they were in desperate need of federal and state assistance to improve the economic and social means for marginalized populations struggling to exist (West, 1986: Wait, 2017). The trickle-down theory applied from Reagan's administration provided lower taxes for the rich with the hopes of this class investing the money into public spaces. As Manning Marble (1983) suggested from his text, How Capitalism Underdeveloped Black America,

The racist/capitalist state under Reagan has proceeded down a public policy road which could inevitably involve the complete obliteration of the entire Black reserve army of labor and sections of the Black Middle class. Simply put, capitalism in urban Black America has led to an unemployment of over $50 \%$ of black youth, the astronomical collapse of black agricultural entrepreneurship, the $41.2 \%$ poverty rate of young black women householders, the $26.8 \%$ of high school graduates among the black poor or the 31,000 black families who had no cash income at all this past year (p. 225).

Capitalism, from Marable's lens, in its new form, became racial violence that rejected black populations seeking an economically sustained existence in their communities. With industries transplanting overseas for cheaper labor, the jobs that once created middle-income revenue became absent (Watkins, 2011; Wilson, 1997). Also, the schools, specifically the vocational education programs, that relied on federal, state, and local tax dollars dried up, which no longer trained and prepared a workforce possessing a high school diploma (Ottenberg, 2019). What made matters worse, the crack-cocaine era wreaked havoc in many of these communities which served as an underground and economical option for young people who were either unemployed, had limited specialization, and work experience (Wilson, 1997). Marble assessed that the trickle-down theory engineered underdevelopment and economic genocide toward communities of color because Reaganomics provided fiscal incentives to the rich rather than toward the city and state governments to support marginalized and working-class populations in need of quality public service systems and programs. As a result, the federal and state welfare and public programs became financially unsustainable eventually paving the way for neo-liberalism to surface as a solution for disadvantaged geo spaces.

The second phase of neo-liberalism emerged during Clinton's presidential terms where disadvantaged populations receiving welfare were provided a time limit to stay on public assistance. President Clinton's Personal Responsibility and Work Opportunity Act soon emerged resonating a Keith Moynihan posture that single-family residents, mostly black and brown, could become economically instructed or taught to transition from low-income housing by acquiring soft market skills and job preparatory training (Radnofsky and Hook, 2012). Essentially, the Moynihan's report correlated the rise of poverty in urban black areas to many poor, single-female headed households. Proponents further asserted that the population's dependency on public assistance programs weakened the American economy by over-relying on a tax system burdened to finance other essential aspects of the American economy such as the Department of Defense, Education, and the Health-Care industry. If carefully planned, orchestrated, and administered, from this neoliberal lens, a significant percentage of the population could strategically become economically independent (Wilson, 1997; Kozol, 2006; Hackworth, 2006); Soon enough, cities across the United States, specifically in Chicago, Philadelphia, and Washington, D.C. took an active wrecking ball to public housing complexes that stood for years as a general eyesore to some onlookers. Social critics of the public housing system further viewed these residential dwellings as underprivileged and segregated spaces that needed removal from a city's geographic landscape to advance isolated and impoverished minority populations.

However, critics of this plan alleged most of the public housing units resided on valuable real-estate like Chicago's Robert Taylor that existed for years near a lakefront area. Thus, displacing poor residents from such a valuable piece of real-estate became as a geo-policy necessity which ushered forth a gentrification plan. (Watkins 2011). Some scholars argue this is where gentrification took a quantum leap to displace or remove the poor from parts of a city seen as too valuable for the real-estate market and housing developers salivating to makeover these areas. (Watkins, 2011; Lipman, 2011; Hackworth, 2006). In transitioning the poor from these vital-economic spaces, the public housing units along with the schools inhabiting these populations would have to disappear to make way for a new residential class.

Julius Wilson (1996) in his text, When Work Disappears argued that despite the notion that the poor situated in public housing apartments could eventually become a trained workforce, the real challenge dealt with changing or correcting the culture of poverty which had long-lasting, generational effects. Modifying the culture of poverty for residents who had been stuck in place for generations in dilapidated housing units meant more than giving a person some training to receive a job. Instead, it meant educating this population on how to change certain mindsets and cultural patterns that influenced specific behaviors that caused the cycle of poverty to flourish - reasons for why Wilson argued that 
educationally redirecting people's behavior and attitudes would take some time; Moreover, mainstream society would have to patiently accept the transitioning of poor people away from troubled environments that resonated years of neglect, inferior schooling, and intentionally jaded and racist public policy practices.

The third, and current phase, of neoliberalism, continued under President Bush and Obama eras where fixing public education became the central focus to properly educate the poor, working class, and those entrapped in decaying cities. The Emergence of No Child Left Behind and Race to the Top served as a way to change urban education which according to these administrations applied "soft bigotry" for years academically under-preparing America's minority populations to compete in the world economy and achieve a quality standard of living (Rhodes, 2012; Lipman, 1998). Therefore, new standards were necessary to augment the failing urban school models that spurred the race-gap while making a segment of the American population unprepared to economically exist in a global market.

\section{Neoliberal Test Reforms}

The standardization movement of testing would soon emerge from Princeton Review, College Board, and Harcourt where they successfully marketed, packaged, and profited from school districts' assessment criteria. Moreover, these industries were able to manage and frame the public schools' curriculum initiatives and achievement benchmarks through their testing protocols. (Dwer, 2017; Ravitch, 2016). Not only were these test companies a part of the Bush-and-Obama eras of school reform to monitor and assess school performance, but also schools not achieving qualifying scores failed students and communities (Watkins, 2011). Policy initiatives were launched to apply a voucher system to education which first emerged in the 50 s when schools were legislated to integrate or share their spaces with black students, and, thus, provided white parents with an "opt out" to send their children to a school outside of their community or district (Gordan, 2014). Later, in the 80s and early 90s, vouchers evolved to provide urban black and brown parents with an ability to transfer their children from a failing or third-tier school to a performing one (Ravitch, 2016; Robelen, 2015). Testing, again, became the quantitative-qualifier of which schools exhibited the best standards, norms, and curriculum for parents to send their children.

The effectiveness of an educator's professional worth became validated based on test results, which continues to present enormous pressures on teachers to abide by scripted curriculums to maintain their posts (Watkins, 2011). Hence, many educators have fled the field because of the curriculum constraints and test stressors caused by this standardized mechanism (Rhodes, 2012). As a recent educator from Florida stated, "I am tired. ... I will not miss what education has become. A soulless industrial education complex where [administration] cares more about the test scores than their faculty or students" (Walker, p. 1). Testing has so disheartened the field of education that it also affects school children who on average spend " 10 days taking district-mandated tests during the school year and nine days taking state-mandated tests" which takes away from a curriculum's ability to have students learn and invest in engaging, relevant, and meaningful instructional topics (Robelen, p. 2). Moreover, overtesting erodes enthusiasm, and joy-of-learning students discover from creatively designed lessons; Lessons that produce cultural and historical topics which improve students' active awareness, conscious, and responsiveness to challenging contemporary topics (Lipman, 1998).

The standard testing model under neoliberal reforms also abides by racist tropes confirming Herrnstein and Murray's (1994) bell curve theory that, "But school is in itself, more immediately and directly than any other institution, the place where people of high cognitive ability excel, and people of low cognitive ability fail" (p. 56). What renders students to perform more admirably in school, from their perspective, deals with students' genetic material, otherwise known as DNA, to yield quality results.

Primarily, testing through neoliberal policies and reforms provided credence to state-and-city public legislators and officials about which schools should close or remain open, to receive limited public funding, particularly in black and brown areas where students often exhibited challenged assessment results. According to Kalyn Belsha and Bill Healy (2018), "Since 1995, eighty-eight percent of school closures occurred in black and brown areas which by the Renaissance 2010 excursion of school closures under Rahm Emmanuel's administration exodus black educators from the profession that once was a little over 40-percent in the classroom in 2000 down to 22-percent by 2015" (p. 2)

Inevitably, the mass departure of failing school models opened the door for the voucher system to accelerate new school models (charter schools) promised to improve the performance of black and brown learners. Private hands and politically connected organizations would take over a number of either closed schools or create new buildings for learners and families frustrated by education's troubled past. School privatization design was to relieve and protect taxpayers from funding failing schools, particularly in minority and marginalized communities, whose settings 
promised to achieve improved results at a cheaper cost. Also, school closures supported neoliberal policy formation to gentrify spaces delegated as inhabitable due to being distraught with crime, violence, and other extreme social maladies. Restructured and redesigned schools would promote the investment of resources, attract businesses, and locate sturdier residents to blighted areas (Watkins, 2011).

Since neoliberal policy planners during the Bush-Obama eras accused the unions of protecting poor educators who undermined the profession and sanctioned failing as a viable option, charter school spaces would occupy non-unionized professionals who worked more hours at a less pay-rate than their district level peers. According to the Department of Education,

The 2013 U.S. Department of Education's Schools and Staffing Survey found that the average salary of a traditional public school teacher was $\$ 53,400$, but charter school teachers earned an average of $\$ 44,500$. This could be because charter school teachers have worked for fewer years at the school where they currently work. There is no information available from this survey about seniority level, though. Overall, charter school teachers earn about 10 to 15 percent less than they would at a traditional public school, no matter what their experience level is. For example, in 2013, Michigan charter school teachers earned an average of $\$ 42,864$, but traditional public school teachers earned $\$ 63,094$ (Perennial Resources International, 2019, p. 2)

Despite having similar state credentials as their colleagues, passing all of the required tests and accredited courses, neoliberal policies sanctioned a "low-ball" salary to educators for teaching a mostly black and brown population of learners who too often were forced to transition from closed schools into charter models (Watkins, 2011). The income disparities have become so significant for where an educator decides to teach that it dictates not only their livelihood but also the quality of living they will have post-teaching in an economy where the inflation rate and costs of living accelerate. Worse, under these revised school policies and protocols, a teacher could be terminated, sometimes without recourse, for not achieving state-and district test benchmarks (Ravitch, 2016).

\section{Displaced}

During the height of school reform, many black educators from failing school structures were released. Where would black-and-brown educators professionally become employed upon receiving a "pink slip" to inform them their services were no longer necessary at that specific space? Unfortunately, many of the teachers had nowhere to go to find employment which caused a great many of them to leave a state to find a job elsewhere or seek out a charter school that would pay them less for their professional credentials (Estrom, 2012).

Becoming employed as a teacher in charter-and-contract models became a difficult task for a black-and-brown teacher, more so for blacks, who were transitioning from a failed model, which caused a decrease in the teaching rank for black educators and affected the black middle class, their families, and the community (Felton, 2017). Recent statistics from the Albert Shaker Institute indicated the percentage of black teachers decreased by 18 percent in Chicago, and on average 13 percent nationally (Ottenberg, 2019). Historically, corporate America has not been kind to black-and-brown people in employing their services (Ravitch, 2016; Wilson, 1996; Marble, 1986). Where this skilled labor class are either overqualified for performing a similar job as their peers or they support the motto of being "Last hired, first fired." Recent investigations by the Chicago Public Teacher Union (2012) found that,

At charters, more than 95 percent of students were black or Latino/a, while only a combined 30 percent of teachers identified as either black or Latino/a, resulting in a diversity gap of 65 percent across charter schools. The UNO Charter Network has a student population that is 95 percent Hispanic, but only 11.6 percent of its teachers identify as Hispanic or Latino/a. The Noble Street Network is composed of 95 percent students of color, but only 19 percent of their teachers identified as black or Latino/a (p. 3).

Not only have the numbers of black-and-brown educators been intentionally downsized by neoliberal school models but also the National Conference of State Legislators argued that when blacks do arrive in a charter-contract model, they are less likely to achieve tenure and possess an attrition rate of 2-years versus 6-years in a traditional public structure (Exstrom, 2012). As studies show, when black educators exist in a school building they are held under tighter scrutiny and protocols and receive less professional empathy (Author, 2016; Lipman, 1998; Delpit, Embid, 2017).

Charter-and-Contract school corporate design has similar hiring features and practices that employ black folks at a lesser rate than their white counterparts. As the Albert Shaker Institute mentioned from their findings: "A higher percentage of black teachers were laid off or quit than Latino or white educators. Nationwide, according to the Federal 
Department of Education, African Americans made up 6.8 percent of the teaching workforce in the 2011-12 school year, down from 8.3 percent in 1990 . (Nearly 83 percent of the teaching workforce in 2011 was white, down slightly from 1990)" (Rigza, 2016, p. 4).

With a disproportionate number of black educators forced from the system in an already profoundly segregated and divided school structure, many students of color have inexperienced white teachers who stay around, on average, in charter-and-contract schools three years before declaring they have had enough (Ravitch, 2016). When charter-and-contract schools declare they cannot find any quality black teaching candidates in their application pool, what they are saying is: "We cannot hire recently fired teachers who happen to be black from failing schools" (Author, 2016, p. 126). Not surprising, the average new charter school located in urban communities has a black employment population of 11.6 percent compared to 85.3 percent of white teachers (Croston, 2016). Of course, some charter-and-contract schools may fare better in terms of black employment trends, yet the cruel fact remains that there exists a considerable number of black educators out of work (Ravitch, 2016; Ritzga, 2016). Job disparities have become so pervasive within education that black children are lucky to discover a teacher of color reflecting, identifying, and relating to their cultural past. Usually, if black teachers work in these charter-and-contract schools, they comprise 42 percent of the instructional support staff, 65 percent of custodial services, and 72 percent of cafeteria workers, which makes this more disturbing because it suggests blacks cannot teach, but they sure know now how to serve (Perry, 2017). In some strange way, Neoliberal education policies have forwarded education into a new Jim Crow practice and policy of hiring people of color, which translates into black people barely having a job in education.

\section{Conclusion: First Class Results, Second Pay Rate}

As edTPA and other professional standardized protocols overconsume the college of education scholars, many critics argue it has helped to create a teacher-shortage (Ravitch, 2016; Watkins, 2011; Apple, 2018). edTPA functions as a state and federal regulated accrediting system that monitors the effectiveness of teaching preparedness programs. Unfortunately, edTPA's guidelines and mandates are imposing which is troubling for a profession struggling to recruit and retain professionals. The teacher-shortage has become so problematic, according to the Economic Policy Institute, some school districts are modifying hiring practices to deliver instruction employing long-term substitute teachers, providing alternative teaching credentials, and seeking "Peace Corps" teacher-volunteers with less experience (Walker, 2019). Worse off is the high poverty school areas which receive a more considerable amount of less qualified instructors with limited resources to support students encountering social-emotional learning issues, traumas, homelessness, and mental health ordeals affecting their learning which results in higher professional turnovers (Gardner, 2008).

The education profession has become so saturated with testing stressors, micromanaged policies, lack of autonomy, and an inequitable teacher-pay gap, a teaching rebellion was bound to evolve to demand first-class pay-and-professional treatment for first-class results; In particular, urban educators are seemingly tasked with greater professional responsibilities and take on more social challenges than their suburbanite peers who on average nationally earn $\$ 69,000$ compared to city teachers aggregate salary of $\$ 51,000$ (Rado, 2016). In Illinois, the salary statistic is more challenging where a teacher in the suburbs can average a salary of $\$ 80,000$ to $\$ 90,000$ versus their counterparts averaging $\$ 69,000$ in Chicago (Rado, 2016). Yet, teachers are responsible for taking the same state qualifying exams to receive licensure and are economically punished for teaching in a school district whose property tax-value is less.

Such income disparities not only further the gender-income gap of what women educators annually earn but also it drives teachers away from the profession, turning off a generation of college students to become teachers, specifically minority males. As a recent study from the American Association of Teacher College Education (AATCE) confirms, only about $3 \%$ of the teaching force are black-and-brown males with the teacher college programs having less than $2 \%$ of a black-and-brown teaching presence (Walker, 2019). Despite AATCE working with various college teaching programs to improve the recruitment and retention of minority educators, without offering a competitive state-wide public teaching salary and financial incentives to work in disadvantaged environments the teaching profession will continue to decrease. Worse, the U.S. economy is suffering from teaching vacancies especially in rural areas where families are forced to relocate from school districts unable to staff positions which leave residential communities desolate and economically hurt (Strauss, 2015). As the Economic Policy Institute suggests, "A teaching shortage deficit not only threatens students' ability to learn but also consumes economic resources that could be better deployed elsewhere" (Walker, 2019, p. 2). Without filling vacancies and reforming education, more communities and cash-strapped geo-spaces will find it too challenging to house schools because they cannot find enough teachers accepting subpar pay for first-class results. 


\section{References}

Ahern, M. (Feb. 27, 2012). Emanuel disavows 25\% of school kids, says CTU. Chicago NBC Chicago-5. Retrieved from https://www.nbcchicago.com/blogs/ward-room/Rahm-Emanuel-Concerned-About-Three-Fourths-of-School-Ch ildren-140617923.html

Apple, M. (2018). The struggle for democracy in education. New York: Routledge. https://doi.org/10.4324/9781315194684

Author. (2016). My schoolhouse is a ghost town: A teacher's story through reform. IN: Authorhouse.

Chicago Teachers Union. (November 30, 2012). Black and white of education in Chicago's public schools (PDF File). Retrieved from https:/www.ctulocal1.org/reports/black-white-chicago-education/

Croston, Robert. (January 6, 2016). A black principal says what it takes to produce more black teachers. Chicago Reporter. Retrieved from https:/www.chicagoreporter.com/a-black-principal-says-what-it-takes-to-produce-more-black-teachers/

Dwyer, L. (May 14, 2017). The standardized test monopoly that secretly runs America's high schools. Good Education. Retrieved from https://education.good.is/features/ap-classes-a-scam-or-smart-move

Embid, C. (2017). For white folks who teach in the hood... and the rest of $y^{\prime}$ all too: Reality pedagogy and urban education (Race, Education, and Democracy). New York: Beacon Press.

Felton, E. (March 31, 2017). What happened when a city full of teachers, most of them black, was fired. Retrieve from https://hechingerreport.org/happened-city-full-teachers-black-fired/

Gardner, W. (January 4, 2008). Combat pay won't work to attract teachers to poor schools. SFGate. Retrieved from https://www.sfgate.com/education/article/Combat-pay-won-t-work-to-attract-teachers-to-poor-3231849.php

Gordan, N. (September 25, 2014). The little rock nine: How far has the country come? The Atlantic. Retrieved from: https:/www.theatlantic.com/politics/archive/2014/09/the-little-rock-nine/380676/

Hackworth, J. (2006). The neoliberal city: Governance, ideology, and development in American urbanism. New York: Cornell University Press.

Herrnstein, R., \& Murray, C. (1994). The Bell Curve: Intelligence and class structure in American life. New York: Free Press.

Hill, L. (2019). The Chicago river: A natural and unnatural history. Carbondale: Southern Southern Illinois University Press.

Hook, J., \& Radnofsky, L. (July 13, 2012). Neoliberalism and education: A reformational-pedagogical perspective (Part 1). Wall Street Journal. Retrieved http://www.scielo.org.za/scielo.php?script=sci_arttext\&pid=S2304-85572017000100002

Howard, C. (May 4, 2019). This fed-up Floria teacher called his profession'toxic.' Here's why he’s walking away. Miami Herald. Retrieved from: https:/www.miamiherald.com/news/local/education/article230032174.html

Kozol, J. (2006). Shame of the nation: The restoration of apartheid schooling in America. New York: Broadway Books.

Kozol, J. (2012). Savage inequalities: Children in America's schools. New York: BroadwayBooks.

Lake, R. J., \& Lydia, R. (June 2015). Chasing the blues away: Charter schools scale up in Chicago. Progressive Policy Institute. Retrieved from http://www.ppionline.org

Lipman, P. (1998). Race, class, and power in school restructuring. New York: SUNY.

Marable, M. (2015). How capitalism underdeveloped black America: problems in race, political economy and society. Chicago: Haymarket Books.

Ottenberg, E. (March 17, 2019). Gentrification, school closings, and displacement in Chicago. The American Prospect. Retrieved from https:/www.commondreams.org/views/2019/03/17/gentrification-school-clOsings-and-displacement-chicago

Perennial Resources International (May 3, 2019). Public V Charter Teachers. Retrieved from https://www.perennialresources.com/salary-forecasts/public-vs-charter-teacher-salaries/ 
Perry, A. (May 31, 2017). Building educational "success" on the backs of fired black teachers. Hechinger Report. Retrieved from https://hechingerreport.org/building-educational-success-backs-fired-black-teachers/

Rado, D. (October 8, 2016). Salaries, support show a divide between CPS, other Illinois school districts. Chicago Tribune. Retrieved from: https://www.chicagotribune.com/news/ct-teacher-salary-comparison-met-20161008-story.html

Rand Corporation. (2019). The role of charter schools in improving education. Retrieved February 16, 2019, from https://www.rand.org/pubs/research_briefs/RB9428/index1.html

Ravitch, D. (2016). The death and life of the great American school system: How testing and choice are undermining education. New York: Basic Books.

Rhodes, J. (2012). An education in politics: The origins and evolution of no child left behind (American institutions and society). New York: Cornell University Press. https://doi.org/10.7591/cornell/9780801449710.001.0001

Ritzga, K. (October 2016). Black Teachers Matter. MotherJones. Retrieved from: https://www.motherjones.com/politics/2016/09/black-teachers-public-schools-education-system-philadelphia

Robelen, E. (June 5, 2015). How Much Testing Is Too Much? The Atlantic. Retrieved from: https://www.theatlantic.com/education/archive/2016/06/how-much-testing-is-too-much/485633/

Walker, T. (April 3, 2019). Teacher shortage is 'real and growing, and worse than we thought.' neaToday. Retrieved from http://neatoday.org/2019/04/03/how-bad-is-the-teacher-shortage/

Watkins, W. (2011). The assault on public education: Confronting the politics of corporate school reform. Chicago: The Teaching for Social Justice.

Wilson, J. (1997). When works disappears: The world of the new urban poor. New York: Vintage.

Wong, A. (February 20, 2019). The U.S. teaching population is getting bigger, and more female. The Atlantic. Retrieved

from https://www.theatlantic.com/education/archive/2019/02/the-explosion-of-women-teachers/582622/ 